\title{
"BROADCAST YOURSELF": O YOUTUBE E AS MULTIPLICIDADES INTERFACIAIS DRAMÁTICAS DO "EU-VÍDEO"
}

\author{
Potyguara Alencar dos Santos ${ }^{1}$
}

\begin{abstract}
For every minute that passes in real time, 60 hours of video are uploaded to YouTube. You can turn that number over in your mind as much as you want; at no point will it stop being incredible. Sixty hours every minute. That's five months of video every hour. That's 10 years of video every day. More video is uploaded to YouTube every month than has been broadcast by the three big TV networks in the past 60 years. And the pace is accelerating: last year the rate was only 48 hours per minute[...] (Grossman, 2012: 12, In. The Beast With A Billion Eyes).
\end{abstract}

Ao intento deste exercício, proponho um artigo aonde relaciono o fenômeno da vídeo-performance virtual difundido pela plataforma do site YouTube $^{2}$ com algumas teorizações sobre as relações interfaciais entre homens, máquinas e espacialidades virtuais. O objetivo em realce é dar empreendimento a uma produção que pense o movimento das performances autobiográficas na internet como casuísticas que inspiram motes reflexivos sobre os temas das relações entre: pessoa, corporeidade, alteridades e virtualidade; relações entre entes humanos e maquínicos/virtuais; subjetividade e ciberespaço; redes de atores de naturezas diversas e suas agencialidades criativas; entre outras possibilidades mutuamente dialogantes.

Algumas das questões acercadas em vista da produção dos argumentos analíticos do ensaio focalizam as relações interfaciais existentes durante a montagem, anexação e difusão das vídeo-performances na rede mundial de computadores. O slogan Broadcast Yourself divulgado no endereço do site faz pensar a dimensão de amplificação e multiplicação das experiências perceptivas dos usuários quando envolvidos com os aparatos materiais e virtuais que vão desde o cenário de gravação de alguma imagem, com todo o conjunto instrumental técnico, até a própria plataforma virtual, onde estão dispostos os aplicativos e softwares de manipulação e divulgação da imagem pretendida.

\footnotetext{
${ }^{1}$ Universidade de Brasília, Brasil.

${ }^{2} \mathrm{O}$ YouTube é uma plataforma da internet que permite que os usuários carreguem e difundam vídeos formatados digitalmente. O site foi criado em 2006 por três funcionários do grupo PayPal, que faz o gerenciamento de conteúdos e pagamentos sobre produtos na rede mundial de computadores (Langan, 2008).
}

Iluminuras, Porto Alegre, v. 15, n. 35, p. 336-355, jan./jul. 2014 
Como o meio interfacial homem-plataforma virtual propõe maneiras de criar "selves" variados, sujeitos em busca de divulgar suas performances e dramas íntimos? Que mundos de subjetivações são articulados com a proposta de um "eu que se autodifunde" e procura gerar alteridades teatrais, embora fortalecidos por operações compartilhadas, repetitivas, plásticas e virtuais? Objetivando desenvolver os alcances argumentativos possíveis às questões em apresentação, o ensaio propõe descrever as contracenações que inspiraram parte da produção de três vídeo-performances lançadas na plataforma virtual YouTube: [i.] a despedida de um garoto com uma grave patologia cardíaca irreversível; [ii.] o cliente revoltado que grava o seu próprio ato de depredação do recinto comercial que motivou sua queixa; [ii.] a imagem banal registrada pelo pai de uma criança que acaba de sair do dentista.

Como eixos teóricos que atinam ao problema analítico definido, procuro relacionar quatro níveis de abrangência que podem contribuir ao desenvolvimento do ensaio. Esses níveis também incorporam três questões que surgem da intersecção de uma proposta de cada autor. No primeiro desses níveis discuto o valor do lugar das experiências virtuais como um "campo de saber" analisável, um lugar de exposição do que Foucault (2010: 18) tratou como "artes da existência"; conceituação a ser discutida a seguir. No segundo desses níveis, sirvo-me da perspectiva das relações radiais entre humanos e não humanos (Latour, 1994; 2001), quando pondero a importância de localizar as agências e os "encaixes" de entes de naturezas diversas que se interacionam para gerar o fenômeno da vídeo-performance. No terceiro e no quarto nível de discussão conceitual relevo duas contribuições teóricas: a perspectiva das multiplicidades constitutivas das relações apresentada nos trabalhos de Deleuze e Guattari (1995) focalizando, principalmente, o conceito de "plano de consistência" - e, num outra ponta, a imagem do "monstro-ciborgue" cedida pela filosofia política de Haraway (1991; 2009). Sobre esse último esquema teórico, o trabalho tende a propor certas reavaliação dos argumentos da autora ao observar que os fenômenos da vídeo-performance e do YouTube além de criarem certos "monstros" que "desessencializam" algumas representações tipificantes dos sujeitos sociais e suas identidades, também acabam dando a esses entes de devires multiplicados algumas situações inescapáveis, como a ritualística da gravação, edição e reprodução de imagens que constrangem indistintamente a ação de todos os usuários do site. O que pretendo reforçar com essa 
observação é que, na trajetória desses ciborgues, mesmo as etapas desconstrutivistas e construtivistas de certas relações criativas são constrangidas por operações e conteúdos repetitivos que não permitem a completa liberdade desses entes dentro de um mundo estético ideado.

Embora híbridos, embora desejantes de certas capacidades e identidades potentes, os ciborgues não deixam de recorrer a certas ritualísticas e processos sociais sistêmicos e constrangedores das suas condutas. A própria imagem do site YouTube como um grande segmento empresarial provedor de comandos e de regras aos seus usuários representa os limites do ideal Broadcast Yourself de difundir a si mesmo e por si mesmo, amplificar seus devires-imagem. Ao final dessa reflexão, o ensaio nos lembra que as "máquinas abstratas" do capitalismo (Deleuze; Guattari, 1994) estão sempre marcando os seus lugares em meio às inúmeras tentativas de agenciamento das situações e condutas, em meio às várias buscas de realização de "corpos-sem-órgãos" potentes.

\section{Multiplicidades dramáticas e o "eu-vídeo". Algumas entradas teórico- metodológicas.}

Esta amostra ensaística sobre o fenômeno da vídeo-performance no YouTube pode ser localiza dentro da já reconhecida tradição dos estudos que relaciona processos de subjetivação contemporâneos e virtualidade, mundos sociais da vida e realidades cibernéticas (Lévy; 2003; Lange, 2008; Cheng et ali, 2007; Leitão, 2012). Como já punha em discussão uma autora que a este trabalho muito interessa, falar em cibernética é recolocar concepções de humanidade, anomalias sociais e individuais numa história desde os humanos, cruzando os não humanos e chegando até as novas máquinas cibernéticas potentes de informação (Haraway, 1991). Por sua vez, tratar de cibernética seria apontar a criação de formas infinitas de negociar, ampliar e multiplicar informações que cruzam, em algum lugar dessas cadeias relacionais, organismos humanos e não humanos que têm suas naturezas discretas reinventadas a serviço de novas interações produtivas. É colocando em tese esse argumento que Donna Haraway encontra na sociobiologia um lugar de fertilidade às novas maneiras de reconstruir naturezas e produzir informações utilizáveis pelo capitalismo contemporâneo. Os corpos 
e suas naturezas - verificadas, comparadas e hibridizadas - respondem aos ideais de potencializar a vida humana, desenvolver competências científicas e ampliar as forças do capital produtivo. Como instância desse capitalismo multilocalizado, as programações virtuais são exemplos dessa amplificação das potencialidades informativas e reinvenção de novas relações sociais. Cenários, dramatis personae relacionais e objetivos são reeditados e reinseridos dentro de realidades fundadas ou pelo signo da reinvenção ou da criação reprodutivista que multiplica as experiências de um real e aproxima tempos e lugares dentro de certos quadros estéticos. Esta é a lógica renascente das performances da videoteca universal do YouTube.

Mas se, aconselhados por Haraway (1991: 12), relevamos também que toda experiência cibernética (ou de retenção e distribuição de informação) deve ser analisada à altura de uma preocupação mais ampla com as "politics of nature" aí envolvidas, seria possível especular sobre naturezas em transformação no caso da nossa unidade de análise: uma plataforma virtual de vídeos? Essa é uma questão semelhante a que dá título a um dos vídeos que analisarei: “Is This Real Life?”. É preciso interrogar se esses vídeos, essas cibernéticas e metáforas de "animais autobiográficos" (Derrida, 2002) são, de fato, uma "segunda vida" (Leitão, 2012: 3) para nos indagarmos se ali existe uma reprogramação de naturezas conceptuais e subjetivas? Conceptuais sobre certas definições societárias relativas ao indivíduo, aos gêneros, às cidadanias, às histórias de vida; e subjetivas relativas a duas interrogações e meta-narrativas incontornáveis aos que gravam e divulgam suas imagens no site: que outro sou na embalagem virtual deste vídeo? Que outro quero ser desde agora? E outra questão possível seria: que outro permaneço ou não permaneço desde este vídeo, neste devir “eu-vídeo”? Que políticas do desejo - para mencionar uma expressão deleuziana - de um "eu-vídeo" coletivizado a outros entes superdependentes, como as tecnologias cronológicas, digitais e virtuais da câmera ao site - são mobilizadas para fazer um "eu-vídeo"?

Lembremos que o objetivo espetacular aqui negociado é aquele imperativo ressoante em todas as operações do site que diz: Broadcast Yourself. O slogan soa como uma campo de permissividades, como uma expressão de uma cibernética dadivosa que está aí para ampliar o indivíduo singular, constrangido na sua intimidade, torná-lo outro, difundir, televisionar seu self. Da poltrona da sala posso contar minha pequena crônica 
diária e de repente tê-la devassada por 100.000 cidadãos do mundo. E assim se explora o objeto desejante da experiência tecnológica do YouTube.

Há, com centralidade, duas entradas teóricas possíveis de serem reconstruídas até se chegar aos modos analíticos e metodológicos mais adequados ao caso desta unidade de análise. Uma delas seria o método da "arqueologia das ideais" de Foucault (2010): como o virtual e, dentro dele, a vídeo-performance se instituíram enquanto práticas sociais amplamente difundidas e legítimas. Uma outra entrada seria a filosofia das multiplicidades de Deleuze e Guattari (1995). Para a arqueologia das ideias, uma pergunta conveniente procuraria no fenômeno da vídeo-performance os conteúdos passadistas e fundantes do gesto ritualístico: gravar e reproduzir-se não em qualquer veículo, mas numa plataforma virtual intitulada YouTube (que traduzido seria algo como: "você-televisão ou você-vídeo"). Como esse fenômeno se inscreve no espaço das práticas modernas de "poder ser" e "deixar ser"? Como o particular dos viventes - suas narrativas de vida e de morte, seus engajamentos no mundo cotidiano, seus distanciamentos com as suas realidades locais em vista de um desejo pela mundialização de suas autoimagens - foram normalizados como praxiologias legítimas e socialmente apreciadas? Como se deu esse esgarçamento do particular para um público que não é de todo público, desde que é o virtual, um campo relacional que tem um locus normativo de acesso a ele? A construção desses problemas é da ordem de pertinência das contribuições foucaultianas. Suas indagações que tentam encontrar nas origens das práticas as "hermenêuticas do desejo" e dos sistemas de poder (Foucault, 2010: 194) que deram condições de possibilidade a certas condutas aceitáveis. Lembrando que poder, saber e prática/experiência são os três planos categoriais que inspiram esta argumentação.

Compreende-se que a partir de uma leitura da proposta de Foucault (2010) o "virtual" possa ser compreendido, ele próprio, como um “campo de saber". Ou seja, um campo relacional de práticas instituídas. Práticas que precisam de uma duração disposta num tempo histórico que as acomodem entre outros modos de vida existentes e permissivos à intrusão das suas regras. Longe de ser tão-só um gesto físico consonante uma manobra de instrumentos, substâncias e materiais encerrados num clico de relações mutuais e integradas (Leroi-Gourhan, 1964) -, a concepção de "prática e experiência" em Foucault faz confundir substratos sócio-ideológicos, transformações históricas em 
corpos de saberes e sociologias contextuais resultantes dos fenômenos de interação dos atores sociais: "entendemos por experiência a correlação, em uma cultura, entre campos de saber, tipos de normatividade e formas de subjetividade" (Foucault, 2010: 193). Nesse sentido, a proposta foucaultiana é importante, antes de tudo, para lembrar que a própria realidade virtual é um espaço constituído por um coletivo de práticas prescritas por moralidades. Como já observava Lévy (2003), o mundo virtual não está livre de repetir ou recriar as normatividades, os preceitos e as categorias fundadoras do mundo não virtual.

Diante do desafio colocado pelo método arqueológico da biopolítica foucaultiana ao contexto de produção deste breve exercício, é conveniente citarmos, e, agora, com mais verticalidade, a importância da proposta desessencializante dos entes da vida, infinitesimal e povoada de unidades relacionais mutuamente interferentes e compostas, inacabadas da filosofia de Deleuze e Guattari. A vídeo-performance cibernética é relacionada nesse momento à imagem do corpo rizomático de entes e concepções que criam e desmontam práticas, produtos estéticos, selves. Assumir os produtos do capital imagético/estético da civilização enquanto organismos instanciais podem ser uma proposta possível a esta filosofia do capitalismo esquizoide. A vídeo-cibernética é muito real nas práticas técnicas e tecnológicas que orquestram a questão: “como posso fazer o meu 'eu-vídeo'?"; uma pergunta tão possivelmente deleuziana quanto "como fazer um CsO” (Deleuze; Guattari, 1995: 23).

O YouTube é a virtualidade de todos os tempos, um upload de 60 horas de vida por minuto, um "plano de consistência" (1995: 12) da virtualização das mito-narrativas sobre a individualidade e a autobiografia. Qual o "plano de consistência" das vídeoperformances que preenchem a sua espacialidade virtual? Uma pergunta possível, se entendermos o plano de consistência como agregado ou contínuo de unidades constitutivas de um ato, de um esquema semiestruturado de ações em potência, um programa de atividades que logo gera um constructo e logo também o desfaz. Abre-se, aqui, à linguagem das "multiplicidades" relacionais e dos "planos de consistência".

Falamos exclusivamente disto: multiplicidade, linhas, estratos e segmentaridades, linhas de fuga e intensidades, agenciamentos maquínicos e seus diferentes tipos, os corpos sem órgãos e suas construções, sua seleção, o plano de consistência, as unidades de medida em cada caso [...] Todas as multiplicidades são planas, uma vez que elas preenchem, ocupam todas as suas dimensões: falar-se-á então de um plano 
de consistência das mutiplicidades, se bem que este plano seja de dimensões crescentes segundo o número de conexões que se estabelecem nele. As multiplicidades se definem pelo fora: pela linha abstrata, linha de fuga ou de desterritorialização segundo a qual elas mudam de natureza ao se conectarem às outras. O plano de consistência (grade) é o fora de todas as multiplicidades. (Deleuze; Guattari, 1994: 11 e 16, grifo meu)

Nesse apurado de definições colocado diante da nossa unidade analítica, "as multiplicidades" poderiam ser referidas aqui ao conjunto de operações que encetam a realização da performance daquele que terá sua imagem registrada (o performatizante), com todos os seus agenciamentos maquínicos aproximados e servindo ao seu número (o conjunto dos materiais e plasticidades do instante da gravação: câmeras, efeitos de luz, disposição espacial, etc.). Enquanto o efeito geral da reunião, disposição e relação dessas unidades humanas e não humanas em interação comporiam as multiplicidades de produtos e sub-produtos de um ato performático, o resultado desse encontro se definiria pela própria realidade do YouTube; aqui definido como um "plano de consistência" rizomático, a experiência imagética em rede, essa "grade", esse "fora" de todas as multiplicidades a que se referem os autores. Esse plano de consistência como uma "besta de um bilhão de olhos" vesgos (Grossman, 2012); ou seja, voltados uns para os outros, a se verem, a se observarem, onde os sujeitos performatizantes se assistem. Os consumidores do site, aqueles que postam as suas vídeo-performances, também apreciam as produções de outros usuários. Em algum momento desse contexto interativo é necessário perguntar se existem usuários passivos e ativos do YouTube: os "vedores", aqueles que apenas assistem aos vídeos, são perfeitos passivos se pensados diante dos que postam suas imagens? Em algum outro momento retornarei ao problema aqui colocado.

Antes, é importante compreender que tanto as ações performáticas de filmar-se amadoristicamente quanto publicá-los na rede vivem uma dupla condicionante que se contradiz: gravar e publicar imagens no YouTube são atos como linhas de fuga, multiplicidades, maneiras diversas de alcançar certas finalidades autorais que só se realizam pelo efeito da reprodutibilidade tecnológica. Há uma mínima técnica de registro e edição de imagens, assim como um procedimento digital padrão de publicação no site que não pode ser desprezado, que é inarredavelmente necessário para o êxito do usuário em ter ser objeto estético disposto na rede mundial de computadores. 
Essa limitante à realização de um voo sem medidas no ato de criação nos faz pensar nesse instante em duas contribuições de análise: uma que é o momento dos "encaixes" necessários dessa rede sociotécnica (Latour, 1994; 2001) - existe um proceder que traz eficácias, mas que também pode criar controvérsias ou novos produtos -, assim também como nos faz pensar no sujeito autoral, na dinâmica de subjetivação que envolve a ação volitiva do indivíduo performatizante. E aí, duas perguntas podem ser colocadas de volta à Haraway (2009) do Manifesto Ciborgue: que monstros, que tipologias de quasehumanos esses sujeitos performatizantes estão procurando criar? Que processos de subjetivação, ou de não aceite de subjetividades estanques, consolidam o projeto mais amplo de construir um "eu-vídeo" para si (um You-Tube)? Assim como Haraway (2009: 97) localizada os "monstros-ciborgues" "3 da ficção científica feminista, creio ser possível tratamos aqui dos monstros-ciborgues produzidos pelo homem ordinário que digitaliza e viraliza sua imagem na rede mundial cibernética.

Esse monstro-ciborgue como um "eu-vídeo" seria exemplar nas inúmeras experiências laboratoriais criativas dos indivíduos ao tentarem performatizar papeis teatrais variados, personas dramáticas à procura de uma identidade virtual, expressões de si que buscam fundarem um self idiossincrático dentro do grande coletivo de personagens cibernéticas. É preciso lembrar que nessa produção também se processam "noções do 'eu", um estado de percepção social do corpo e da espiritualidade (Mauss, 2005: 371$)^{4}$. O interesse é que cada vídeo seja "um vídeo", um experimento dramático único propondo a produção de uma segunda experiência estética única por parte dos apreciadores. O esforço é por ter o vídeo mais acessado, a obra mais divulgada e comentada. É por essa busca de uma idiossincrasia imagética, por um esforço em tentar ir contrário a rever as narrativas dos padrões societários da comunidade não virtual, não digital, à maneira dos monstros ciborgues da ficção científica feminista, que trato aqui dessas produções enquanto experimentos de criação de "monstros-ciborgues". O que se argumenta é que no caso das personas dramatis do YouTube e do laboratório estético

\footnotetext{
${ }^{3} \mathrm{Na}$ definição da autora, "monstros dos mundos ciborguianos estão corporificados em narrativas não edípicas, obedecendo a uma lógica de repressão diferente, a qual, em nome de nossa sobrevivência precisamos compreender [...] Os monstros-ciborgue da ficção científica feminista definem possibilidades e limites políticos bastante diferentes daqueles propostos pela ficção mundana do Homem e da Mulher" (Haraway, 1991: 39 e 97).

4 A definição de "eu" para Mauss é compreendida não como categoria, mas como "noção"; ou seja, maneiras societárias diferentes de se compreender e fazer uso das expressões corporais e espirituais.
} 
do Broadcast Your(self) também estamos produzindo "bits e bytes que circulam, indistintamente, entre corpos humanos e corpos elétricos, tornando-os igualmente indistintos: corpos humano-elétricos" (Haraway, 2009: 13, grifo meu).

Há pouco me referi às "articulações" das redes sociotétnicas que propiciam a fabricação e difusão do "eu-vídeo". A importância de se falar dos coletivos de unidades relacionais constitutivos dessa experiência estética ocorre pelo interesse de definir quem são os quase-objetos que povoam esse fenômeno, como também exercitar o princípio lançado pela simetria latouriana: "a possibilidade de livra-nos dos cortes epistemológicos" (Latour, 1994: 93) que impôs níveis de discrição (e descrição) para um "nós" que raciocina, interpela, intervém, e "eles", que são interpelados, vasculhados. Buscar as articulações, os "erros e controvérsias", assim como as "naturezas-culturas" (Latour, 1994: 96) que geram certos fenômenos responde à necessidade de reconhecer a grande cadeia organizacional que permite a reprodução e transformação de certas realidades. A perspectiva simétrica responde ao interesse tanto de localiza as "substâncias" quanto as "proposições" de uma dada relação, discernir tanto os "humanos" quanto as unidades "não humanas". Como conclui Latour (2001: 171) em A Esperança de Pandora, são as condicionantes da história dos contatos entre humanos e não humanos e a própria existência das substâncias em interação que interessam à proposta em análise. Acredita-se evitar, seguindo esse princípio da simetria, a dicotomia que segregava e subordinava os condicionantes "sujeito e objeto". A proposta em tela observará o autor na última obra referida - é não culpar nem Pasteur (o cientista) nem os micróbios pelo estado de uma relação, mas sim dar relevância ao que vai chamar de “articulações ou mediações" (Latour, 2001: 171); os momentos onde essas unidades se encontram, adensam as suas relações e complexificam uma cadeia interacional em rede. Define-se que

a descoberta-invenção-construção do fermento láctico exige que cada um dos artigos de sua associação receba o status de mediação, isto é, de ocorrência que não seja nem uma causa completa nem uma completa consequiência, nem inteiramente um meio e nem inteiramente um fim (Latour, 2001: 179)

A vídeo-performance depende da reunião, mediação e articulação de inúmeras unidades participativas em mutualidade relacional para que o "evento" tenha sua eficácia esperada ou controvertida: no caso do "eu-vídeo", as possibilidades são de 
tornar-se um "viral" visto por milhões de pessoas em todo o mundo, que seja postado em blogs, sites e difundidos por centenas de espaços virtuais, ou, por outro lado, transformar-se em mais um vídeo com poucos acessos a povoar a plataforma do YouTube. Reforço aqui, servindo-me do princípio simétrico e dos conceitos de "articulação/mediação", que é importante tentar localizar os coletivos que povoam a existência do fenômeno da criação e difusão dessas vídeo-performances, assim como verificar os seus encaixes, suas correspondências. É nesse nível que a contribuição de Latour $(1991 ; 2004)$ tem expressão no contexto deste ensaio.

Por fim, um questionamento que não pode ser excluído dessa explanação conceitual é o que relaciona a performance desses "animais autobiográficos" (Derrida, 2002) com a dimensão da experiência corporal, da corporificação desse devir virtual, desse "eu-vídeo". Se viver é "reduzir continuamente o mundo ao seu corpo, a partir do símbolo que ele encarna" (Le Breton, 2011: 7), então que representações de si têm expressão nesses corpos performáticos? A perspectiva de Le Breton (2011) é importante ao nosso espaço de discussão à medida que consegue relacionar "corpo" e "modernidade", chamando atenção que

a preocupação moderna com o corpo, no seio de nossa "humanidade sentada" é um indutor incansável de imaginário e de práticas. "Fator de individuação" já, o corpo redobra os sinais da distinção, exibe-se à maneira de uma fazer-valer (Le Breton, 2011: 10).

Embora passível de crítica pela sua distinção estrita de uma concepção de corpos nas sociedades modernas (o corpo enquanto símbolo da diferenciação e individuação) e nas sociedades tradicionais (para as quais o "corpo não se distinguiria da pessoa"), as observações do autor são importantes tanto por nos lembrar da centralidade das experiências sociais "no corpo", como para nos fazer pensar sobre as possibilidades de desconstrução dessas mesmas experiências corporais. Para tratar da perspectiva desconstrutivista das representações corporais, as contribuições de Butler (2003), ao falar dos "atos parodísticos", e de Haraway (2009), ao tratar dos "mostros-ciborgues", parecem ser mais focadas na maneira de abordar as iniciativas de hibridizar, confundir e recriar certas representações que foram historicamente encerradas na "dualidade" corporal de gêneros, por exemplo.

Iluminuras, Porto Alegre, v. 15, n. 35, p. 336-355, jan./jul. 2014 


\title{
A besta de um bilhão de olhos: artes da existência de um "eu-vídeo"
}

\begin{abstract}
Vlad (interviewed): We have a strict rule [governing] our society that there are some things that should never be seen, should never be known, [which is] more for our protection than yours. If people knew that we were doing such things, [we] would be punished, so you'll never know our real names or our real faces but you will know our entertainment (Lange, 2008: 372).
\end{abstract}

As descrições dos vídeos que serão feitas a seguir não compreendem os espaços de produção das vídeo-performances; ou seja, não se faz uma descrição do backstage de gravação, dos seus ambientes de produção e edição. Também não são apresentadas falas autorais dos performers. A unidade de análise aqui em exposição é o próprio vídeo à maneira como qualquer leitor deste ensaio pode acessar agora mesmo apenas visitando a plataforma do YouTube na internet.

As vídeo-performances analisadas serão as seguintes: [i.] a despedida de um garoto com uma patologia cardíaca incurável; [ii.] o cliente revoltado que grava o seu próprio ato de depredação do recinto comercial que motivou sua queixa; [ii.] a imagem banal registrada pelo pai do seu filho que acaba de sair do dentista. Justifica-se a escolha dessa amostra de vídeos por dois motivos. O primeiro deles é que todas essas performances são como monólogos, narrativas biográficas que enquadram com centralidade as histórias de personagens individuais. Todos os vídeos são produções clássicas dos usuários do YouTube que procuram desenvolver e expor a partir de si, da figuração de uma personagem e de uma ação dramática que marca uma identidade, o que Foucault (2010: 198) chamaria de "artes da existência":

[...] artes da existência. Estas devem ser entendidas como as práticas racionais e voluntárias pelas quais os homens não apenas determinam para si mesmos regras de conduta, como também buscam transformar-se, modificar-se em seu ser singular, e fazer de sua vida uma obra que seja portadora de certos valores estéticos, que corresponda a certos critérios de estilo.

O outro motivo é o efeito que no universo do ciberespaço é chamado de "reação virótica" de um vídeo. Essas vídeo-performances renderam milhões de "acessos" e “compartilhamentos" (postagens do vídeo em outras plataformas da internet por vários usuários). Essa segunda justificativa abre-se à possibilidade de exercitarmos aqui uma "teoria estética da recepção" quando nos perguntamos: o que garante, em conteúdo e 
forma, que esses vídeos se estendam pela realidade virtual como verdadeiras experiências rizomáticas emendando e reconstruindo diversas relações? Embora esse questionamento sobre uma teoria da recepção possa ser colocada, o que nos interessa de fato é a descrição e análise da forma-conteúdo das artes da existência expressas em casa vídeo. É aconselhável que antes de cada tópico a seguir, o leitor aprecie os conteúdos de cada um dos vídeos mencionados por cada um deles.

\section{My Final Goodbye: Shaun Wilson Miller ${ }^{5}$}

Oi, pessoal! Eu tenho algumas notícias ruins para contar a todos vocês... Eu tenho uma rejeição crônica no coração e... eu não estarei aqui por tanto tempo como pensei $[\ldots]^{6}$.

É preciso olhar a interface completa, o layout de dentro para fora, do centro do vídeo para as margens da tela, saindo desse quadro, chegando até você. No vídeo, Shaun Wilson Miller, um garoto estadunidense com uma patologia cardíaca sem chance de reversão, despede-se. De quem? O seu vídeo é mais uma postagem digital lançada numa configuração ciberespacial de outros vídeos e de outras despedidas. Não existe um receptor específico da mensagem. O vídeo marca a despedida de alguém, só isso. A imagem é para todos e para ninguém. Dentro do grande painel de outras narrativas pessoais, o vídeo de Shaun é um esforço por individualizar o seu conteúdo dramático, um exercício de propagação de um "eu-vídeo".

Shaun aproxima a câmera do rosto, de modo que ela enquadre a menor das suas expressões. Shaun parece a todo o momento aflito. Ele quer que o flagremos na sua aflição. O vídeo anuncia: "não tem saída”. O close indefectível, seguramente centralizando um rosto e sua despedida. O "eu-vídeo" de Shaun não recorre aos grandes excessos de um cenário ou de um ambiente cuidadosamente produzido para que um certo ator se pronuncie. O vídeo é um discurso autotélico, em forma de monólogo, que não permite nenhum tipo de subestrutura que não o próprio sujeito; o próprio "animal autobiográfico" representativo de um humano lembrando a si próprio o destino dramaticamente anunciado. Quem morre quando o vídeo acaba: Shaun, acometido pela

\footnotetext{
${ }^{5}$ Os títulos dos tópicos são também os títulos dos vídeos disponíveis no site do YouTube.

${ }^{6}$ Disponível em: [Link]. Acessado em: 04 Ago. 2013. [Link].
} 
sua patologia cardíaca, ou seu duplo existencial, sua "arte da existência", seu "euvídeo"? O vídeo como esforço de eternização é negado por um anúncio de fim da existência da realidade espacial-temporal do momento de registro das imagens. É a ausência preconizada que se plastifica em vídeo e na existência virtual que vai se multiplicar, criar seus múltiplos cibernéticos como uma sobrevida do garoto que se despede.

Voltemos à interface e às "mediações" (Latour, 2001) que oferecem condições de possibilidade à realização da imagem. Retornemos aos materiais, aos quase-objetos e também aos meios interfaciais sujeito dramático/maquinaria/ciberespaço que surge como a grande peça relacional, o representativo "plano de consistência" que apresenta o sistema completo e funcionando. "Funcionar" significa aqui a existência de um vídeo ativo, um produto que esteja na rede, e que tenha um conteúdo aberto. Além de acessível, a vídeo-performance permite na sua interface que os usuários vedores comentem, positivem ou negativizem o seu conteúdo.

$\mathrm{Na}$ contemporaneidade, quase todos os usuários assíduos da internet sabem dos manejos para a utilização do site. As disposições das ferramentas são comuns a todos os vídeos: o "produtor da imagem", o performer, possui uma conta a qual associa o seu vídeo, que é em seguida lançado na plataforma do YouTube, que por sua vez trata de associar o produto a uma universo de outros. As pequenas janelas que surgem umas sobre as outras, quando procuramos ativar um vídeo, são aplicativos publicitários que garantem a possibilidade de visualização de outras gravações. Um título e uma "imagem de capa" (a primeira imagem da gravação que é colada no ícone do vídeo) garantem que outros usuários possam acessá-los. A partir daí, quem "viraliza” a vídeo-performance de um Shaun, por exemplo, são esses usuários vedores que podem colá-la em páginas de blogs, nas suas contas no Facebook, distribuindo através de e-mails coletivos, de grupos de discussão, etc. É pelos usuários vedores que o "eu-vídeo" de Shaun povoa o universo cibernético, são dos seus atos que se desdobram as inúmeras mediações e composições de multiplicidades que produzem a eficácia do vídeo.

Primeiramente, o vídeo da despedida de Shaun aparece associado a uma centena de outros que estão distribuídos numa barra de rolagem. Outras performances podem ser instantaneamente acessadas, as experiências visuais podem ser rapidamente construídas e desfeitas. A interface virtual/maquínica - ou seja, um computador, os seus 
entrecruzamentos de softwares e os conteúdos da virtualidade - possibilitam que as operações sejam rápidas e fragmentárias, capacitam que as opções estéticas sejam várias e estejam todas abertas ao deleite dos apreciadores do site. O segredo da eficácia de funcionamento do sistema maquinal e estético que engendra a obra está na "duração", na permanência diante do vídeo, apreciando e se emocionando com as suas propostas visuais. O segredo insuspeito é o mesmo que sempre incomodou as "artes da existência" oferecidas pelo cinema: “como evitar que a imagem morra antes do expectador?". Como evitar que Shaun morra? As multiplicidades dramáticas e interfaciais de um fenômeno que nos condói completa um ciclo fenominístico com várias vidas, com vários entes. Shaun e nós somos possibilitados, dentro da experiência do nosso encontro, por uma população de entes não humanos que perdem as suas destinações simplesmente maquínicas para associar, emotivamente, patologicamente (Pathos), centenas de milhares de sujeitos dramáticos. A "grade", esse "fora" das relações de dentro do "plano de consistência" é, ele também, um corpo que faz parte de um encontro emotivo entre nós, o YouTube e a sobrevida virtual do pequeno Shaun.

\section{"Solucionou? Não, Mas Estou Satisfeito": Dia de Fúria.}

Eu juro que não queria fazer o que eu vou fazer, mas às vezes a gente é tão humilhado!

Uma proposta espetacular poderia ser um homem portando um martelo e descarregando sua fúria nas mercadorias das prateleiras de uma loja da qual possui uma queixa por não reembolso de uma mercadoria já devolvida. Longe de ser um quadro apelante de um filme, um roteiro de ações ideadas, o desenho cênico que se faz é exatamente o campo de ações do Rodrigo, o cliente que, desistindo de apelar pela escuta dos seus direitos, instrumentaliza o corpo com um martelo e uma decisão: "Eu vim buscar o meu prejuízo, agora!”. Sem mais, Rodrigo entra na loja de construção civil e, pedindo que os funcionários não intervenham na sua ação, martela cubas esmaltadas de pias, vasos sanitários e azulejos.

\footnotetext{
${ }^{7}$ Disponível em: [Link]. Acessado em: 04 Ago. 2013.
} 
O campo de intervenções desse "eu-vídeo" encontra na câmera que o performer leva na mão enquanto destrói as mercadorias da loja o centro das ações dramáticas. Para além das volições individuais, para além do imediatismo da interação, as razões da performatização da fúria estão na possibilidade do registro fílmico, do instante cênico impresso em pixels e em áudio. Antes de postar o vídeo na sua conta junto à plataforma virtual do YouTube, Rodrigo já se comunica conosco. Dentro da loja, ao verter sua raiva, o performer já encontra os seus destinatários, os usuários da sua conta virtual. $\mathrm{O}$ seu objetivo é destinar-se à imagem, lançar mão de um roteiro desejado de ações interventoras. A eficácia é a experiência de si, as artes da existência convertidas no controle e descontrole sobre os atos possíveis.

Nessa intervenção, onde o "eu" (aquele que exerce o ato dramático) da ação e o "eu-vídeo" (aquele que registra o seu próprio ato dramático) já coexistem, um falando para o outro, dialogando por estímulos mútuos, revela-se o fabrico de um "monstrociborgue". Entende-se que o monstro-ciborgue é este que discorda das previsíveis maneiras de intervir: o cliente passivo que entra pela quinta vez na loja para demandar a observância dos seus direitos. O "eu-vídeo" aqui, o nosso monstro-ciborgue que nega as qualidades tipológicas morais do cliente pacificado e aceitante da impossibilidade de resolver o seu problema, interage e age no/com o mundo subvertendo e recriando o que Haraway (2009: 88) chamou de "estruturas do desejo"; ou seja, reconhecidos os modos codificadores de definições de gênero, de cidadão e cidadania, de mulher, de sujeito de direito, o agente se reinsere, por um outro plano de consistência (as ações, os objetos da ação e as volições e devires), dentro do espaço de um "eu" potente ideado. Uma tentativa de significação etimológica pela raiz greco-latina da palavra "drama" nos daria uma tradução como "eu faço"; o pathos dramático é aquele que leva o sujeito a fazer com as suas próprias forças, criando com isso a sua própria destinação (Szondi, 2011; Steiner, 2006). Embora a pessoa dramática também seja aquele que inconscientemente é conduzida a certos fins inconscientes, essa destinação dramática ainda é auxiliada por certas imagens previsíveis que podem precipitar esse sujeito a uma ação desejada. Daí advém o conteúdo moralizante do discurso farsesco de toda narrativa dos sujeitos que agem e se deixam agir pelo pathos.

O monstro-ciborgue ainda seria esse estado que Haraway (2009: 55) trata como o “desejo de um outro", a não abastança de ser somente um “eu”, um chamamento 
sobrecarregado de imagens da modernidade e do seu mal-estar. A negativa da (in)corporação dos caracteres normativos, das "técnicas e cuidados de si" (Foucault, 2010) mais previsíveis, é o motivo de ação desse monstro. O “eu-vídeo” já se comunica como um outro de si, aquele cibernético, aquele virtual, ele já o é. Nesse estado de uma realidade física, Rodrigo já explora a comunicação futura com uma audiência, o espetáculo de montar-se num roteiro possível de ações já é uma interação e intervenção numa virtualidade, num plano maquínico/cibernético de consistência. Desde que o ato foi impugnado diante da câmera já existem as "mediações" interfaciais e radiais desse "eu" existencial e o "eu-vídeo". Temos um ciclo interativo consistente destinado a fazer comunicar o fenômeno performático, os pixels da imagem, a plataforma virtual e os seus vedores, os usuários do site. E dos vedores - que por último são alcançados pela eficácia virótica do ato - de novo ao performer. Sim, porque entre os encaixes dessa interface cria-se o dispositivo virtual dos "comentários": os apreciadores da vídeoperformance comentam o seu conteúdo. Em mais de um comentário feito sobre o vídeo em descrição lê-se: "Parabéns pela coragem e atitude!”. E é nesse momento que o desejo por um outro "eu" espelhado na performatividade do "eu-vídeo" difunde-se como vírus também em direção aos espectadores. Continua desde aí o fluxo de sujeitos, ações e encaixes que movimentam as redes de relações concretas e abstratas.

\section{David After Dentist: "Is This Real Life?"}

\section{"Yeah! This is real life!"”.}

A banalidade como um conteúdo expressivo. Um dia de consulta ao dentista, uma criança ainda anestesiada pelo efeito de alguma intervenção odontológica e um pai que filma cada instante desse momento aparentemente sem surpresas. No banco traseiro do carro, David pergunta do alto dos seus sete anos para o pai que registra as imagens: “Esta é a vida real?". A pergunta tem um duplo alcance, ampliando-se em duas direções. Se perguntar se aquela é a vida real produz um destaque tanto no cotidiano das ações imediatas, no plano das agências que compõem o momento da performance que

\footnotetext{
${ }^{8}$ Disponível em: [Link]. Acessado em: 16 Jul. 2013.
} 
está sendo registrada, como também chega até os seus espectadores, que são surpreendidos se aquela vida, a vida de David que está sendo transmitida via plataforma virtual, é a vida real.

Qual é a vida real? Pergunta que se repete nas experiências dos usuários da maioria das plataformas da internet, uma demanda retórica por sentido que coloca em confronto as ideais formuladas sobre as realidades físicas e digitais. Questionamentos como esse podem ser analisados, por exemplo, nas intervenções dos usuários dos sites de jogos virtuais que reconstroem ciberneticamente uma segunda vida, passando a programar suas ações em cenários e contracenações absolutamente virtualizados; vide os estudos de Leitão (2012) sobre o jogo Second Life.

No contexto da vídeo-performance, a indagação sobre a realidade daquela experiência de vida nos reporta mais uma vez ao plano de consistência, a esse fora composto, multiplamente povoado de entes relacionais humanos e não humanos. A própria cadeia de ações performáticas que oferece unidade a essa "vida possível" do pequeno David é propiciada por um momento existencial próprio, onde a ideia de filmar se alia a um instante fenominístico do sujeito performático - uma cena banal: David e seu mal-estar após uma consulta odontológica. E nas extremidades das outras mediações que envolvem não humanos e o cenário próprio da digitalização da imagem e sua virtualização virótica na rede mundial de computadores, observa-se o próprio vídeo em si, editado e anexado à plataforma, associado a uma conta e seus usuários.

O eu-vídeo de David é a prova de que o banal cotidiano, dentro do seu plano de causas, pode ser um organismo tão expressivamente dramático como os eu-vídeos de Shaun e de Rodrigo, que tentam conquistar os apreciadores do site pela exposição existencialmente verticalizada das suas histórias dolorosas de vida. Dos desejos complexamente formulados às manobras banais e hilárias da vida cotidiana, o YouTube facilita as mediações de sentimentos e suas expressões. Os encaixes entre os meios performáticos, maquínicos e virtuais e suas ampliações radiais em direção a vários outros modos de "viver" as experiências do site criam e fortalecem entes potencialmente outros, vidas dramáticas extensivas que chegam até nós facilitadas por unidades mínimas e interconectadas. Como lembra Latour (2001), a vida já estava lá, o meio bacteriológico já havia se instalado antes do encontro fenominístico com o cientista "vedor", analista. Assim também como o quadro da vida de David - um espelho para 
todas as experiências existenciais íntimas de outras crianças da sua idade - também já estava lá. O YouTube agiu nesse momento desafogando o mundo íntimo do particularismo de cada vida isolada em busca de fazer existir formas superpopulosas de afinidades entre sujeitos fisicamente distantes, mas virtualmente avizinhados. O que esses encaixes entre quase-objetos propiciaram foi o destaque, o descolamento e o novo acoplamento desse quadro da vida de David a um lugar de difusão e ampliação das possibilidades de visualização desse momento particular. De repente, essas unidades lógicas mínimas - dos pixels da câmera (digitalização) aos bytes de velocidade da internet - estão participando de um momento sentimentalmente real da vida desses sujeitos dramáticos. A comunidade de unidades que hoje compõe as experiências nos mundos da vida em sociedades contemporaneamente conectadas, e que obrigam as ciências sociais a reavaliarem os desdobramentos dos usos e reprodução de novas naturezas relacionais, de repente passa também a fazer parte de uma "comunidade de sentimentos" interfacialmente construída por entes humanos e não humanos (Descola, 2011). Ao final, a resposta à pergunta do pequeno David pode ser lida como um questionamento sobre a "natureza" dessas multiplicidades existenciais onde tudo parece conter vida: “Sim, esta é a vida real!” - responde o pai do garoto por trás da gravação.

\section{Conclusão e breve reanálise das pertinências teóricas}

Antes de reafirmar certas análises negativistas e mercadológicas feitas sobre o YouTube nos últimos anos (Lange, 2008; Cheng et ali, 2007), o que este ensaio procurou frisar foi que a plataforma cibernética pode ser compreendida como um plano de consistência (Deleuze; Guattari, 1994) que, entre outras intervenções e acoplamentos entre a vida cotidiana e as múltiplas realidades performáticas, é capaz de propor: uma desessencialização das práticas sociais humanas, quando propicia a criação de certas artes e expressões de si (Foucault, 2010) e instaura um meio de vivência comum entre unidades humanas, maquínicas e virtuais; uma possibilidade de reconhecimento dos "encaixes" e manobras acessadas na composição dessas redes relacionais (Latour, 2001); uma vivificação dramática de figuras e instantes performáticos desejantes de expressar certas singularidades das experiências estéticas e subjetivas; um experimento 
ou narrativa da contemporaneidade que muito pode nos servir como laboratório analítico para falarmos dessas

[...] máquinas de visão melhorada, de reações mais ágeis, de coordenação mais precisa. Máquinas de guerra melhoradas de um lado e outro da fronteira: soldados e astronautas quase "artificiais"; seres "artificiais" quase humanos. Biotecnologias. Realidades virtuais. Clonagens que embaralham as distinções entre reprodução natural e reprodução artificial (Haraway, 2009: 12)

É conveniente propormos que um desenvolvimento dessa escolha de análise possa apontar, num outro momento, para o fato de que embora a "virtualidade e a performatividade" sejam meios que buscam recriar certos agenciamentos singulares da subjetividade individual (Goldemberg, 2001), não deixam de exercer o caráter repetitivo e normalizado que revestem todas as experiências no ciberespaço. Qualquer originalidade do ato performático é original dentro de certas condicionantes maquinais e virtuais que permitem a difusão e categorização de uma manobra desejada. A eficácia desses atos ainda depende, em grande medida, de certos nivelamentos entre as expressões subjetivas, as maneiras de registrar e eternizar essas expressões e as maneiras de difundi-las. Como campo de intervenções finais, o YouTube cria possibilidades às singularidades, mas também o faz no limite da suas potencialidades e interesses políticos. Ao final, o que podemos contar de novo é que, como toda rede expansiva, como toda comunidade híbrida que ocasiona várias outras transformações, só podemos esperar pelas novas destinações que as relações entre entes e unidades de naturezas variadas irão tomar ao sabor de uma observação comum a vários teóricos da pós-modernidade presentes neste ensaio: as multiplicidades criativas não podem "ser", elas estão "sendo", constantemente. Fazendo difundir, o YouTube se produz enquanto uma realidade vivificada, comunal, interfacial e duplicadora da sua própria promessa: difundir as performances virtuais é também espalhar as interfacialidades que produzem esses vídeos e a sobrevivência da própria plataforma.

\section{Referências}

BUTLER, Judith. "Inscrições corporais, subversões corporativas" e "Conclusão: Da Paródia à Política”. In. Problemas de gênero. Feminismo e Subversão da Identidade. Rio de Janeiro: Civilização Brasileira, 2003, p. 185-217. 
CHENG, $\mathrm{Xu}$ et ali. Understanding the characteristics of internet short video sharing: YouTube as a case study. [cs.NI], 25 Jul. p. 1-9, 2007.

DELEUZE, Gilles; GUATTARI, Félix. "Introdução: Rizoma". In. Mil Platôs. São Paulo: Editora 34, 1995a, p. 10-36.

. "28 de novembro de 1947. Como criar para si um corpo sem órgãos". In. Mil Platôs. São Paulo: Editora 34, 1995b, p. 8-27.

DERRIDA, Jacques. O animal que logo sou. São Paulo: UNESP, 2002.

DESCOLA, Philippe. "Prologue". In. HOUDART, Sophie; THIERY, Olivier. Humains, non humains. Comment repeupler les sciences sociales. Paris: La Découverte, 2011, p.17-21.

FOUCAULT, Michel. "Os usos dos prazeres e as técnicas de si". In. Ética, sexualidade, política. Rio de Janeiro: Forense Universitária, 2010, p. 192-217.

GOLDBERG, Roselee. Performance art: from futurism to the present. London: Thames \& Hudson, 2001.

GROSSMAN, Lev. "The beast with a billion eyes". Time, Monday, Jan. 30, 2012, p.12-16. Disponível em: [Link]. Acessado em: 01 Ago. 2013.

HARAWAY, Donna. "Nature as a system of production and reproduction". In. Simians, cyborgs, and women: The reinvention of nature. New York: Routledge, 1991, p. 7-70.

- "Manifesto ciborgue: Ciência, tecnologia e feminismo-socialista no final do século XX". In. TADEU, Tomaz. Antropologia do ciborgue. As vertigens do pós-humano. Belo Horizonte: Autêntica Editora, 2009, p. 33-118.

LANGAN, Patricia G. "Publicly private and privately public: social networking on YouTube". Journal of Computer-Mediated Communication, v. 13, p. 361-380, 2008.

LATOUR, Bruno. Jamais fomos modernos: ensaio de antropologia simétrica. São Paulo: Editora 34, 1994.

. A esperança de pandora: ensaios sobre a realidade dos estudos científicos. Bauru, SP: EDUSC, 2001.

LE BRETON, David. Antropologia do corpo e modernidade. Paris: PUF, 2003.

LEITÃO, Diniz. "Entre primitivos e malhas poligonais: modos de fazer, saber e aprender no mundo virtual Second Life”. Horizontes Antropológicos, UFRGS, v. 18, p. 255-285, 2012.

LEROI-GOURHAN, André. Le geste et la parole. Technique et langage. Paris: Albin Michel, 1964.

LÉVY, Pierre. O que é o virtual? São Paulo: Editora 34, 2003.

MUASS, Marcel. "Uma categoria do espírito humano: a noção de pessoa, a de "eu". In. Sociologia e antropologia. São Paulo: Cosac Naif, 2005.

STEINER, George. A morte da tragédia. São Paulo: Perspectiva, 2006.

SZONDI, Peter. Teoria do drama moderno [1880-1950]. São Paulo: Cosac Naif, 2011.

Iluminuras, Porto Alegre, v. 15, n. 35, p. 336-355, jan./jul. 2014 